\section{Tolvaptan for treatment of iatrogenic hyponatremia}

\section{Dhaval Shukla}

A 9-year-old girl, underwent surgery for hypothalamic astrocytoma. She had a normal hormonal profile before surgery. Her weight was $49 \mathrm{~kg}$. She underwent hourly urine output monitoring, daily serum sodium and serum and urine osmolality monitoring [Table 1]. She did not have any neurological deficits after surgery. From the third postoperative period, she developed diabetes insipidus. She received vasopressin 5 units subcutaneously for every episode of urine output more than $200 \mathrm{ml} / \mathrm{h}$. As she required frequent injections of vasopressin, she was started on the oral tablet desmopressin $100 \mu \mathrm{g}$ daily. On the third day of desmopressin treatment, she developed the hyponatraemia. The desmopressin was stopped and 3\% hypertonic saline was started to target increase in serum sodium concentration by $0.5 \mathrm{mEq} / \mathrm{h}$. Her hyponatraemia worsened in spite on hypertonic saline infusion. The central venous

Department of Neurosurgery, National Institute of Mental Health and Neurosciences, Bengaluru, Karnataka, India

Address for correspondence:

Dr. Dhaval Shukla, Department of Neurosurgery,

National Institute of Mental Health and Neurosciences,

Bengaluru - 560 029, Karnataka, India.

E-mail: neurodhaval@rediffmail.com pressure monitoring was not done to determine the volume of the patient. There was no significant change in heart rate and blood pressure indicating that the volume was probably normal or more. The urine output reduced as the serum sodium concentrations dropped. The serum osmolality reduced and urine osmolality increased during hyponatraemia. From the available data, the hyponatraemia seemed to be due to hypervolaemia (desmopressin intake). A trial of fluid restriction was not given as the cause of hyponatraemia was definitely desmopressin. Hence she was started on oral tablet tolvaptan $15 \mathrm{mg}$ daily. On the second day of receiving tolvaptan, her serum sodium concentration started increasing [Figure 1]. She received tolvaptan for 3 days. Her serum sodium gradually normalised, and on day 18 after surgery, her serum sodium concentration was $137 \mathrm{mEq} / \mathrm{L}$. Her diabetes insipidus settled and she did not require any hormone supplement. At 6 months of follow-up, she has a normal hormonal profile.

Hyponatraemia is defined as a serum sodium levels $<135 \mathrm{mmol} / \mathrm{L}$. Hyponatraemia is common and can be challenging to manage. It is often encountered in neurosurgical practice. This disorder is most of the time due to the syndrome of inappropriate antidiuretic hormone (SIADH) secretion, which causes euvolemic or hypervolaemic hyponatraemia. The causes of SIADH are malignant disease, intracranial pathology and some medications. ${ }^{[1]}$

The only pharmacological therapy approved for the treatment of hyponatraemia due to SIADH is the class of vasopressin receptor antagonists (vaptans). ${ }^{[1,2]}$ 
Table 1: Daily serum sodium, urine output, serum and urine osmolality chart

\begin{tabular}{lcccc}
\hline Day & $\begin{array}{c}\text { Serum } \\
\text { sodium } \\
\text { (mEq/L) }\end{array}$ & $\begin{array}{c}\text { Urine } \\
\text { output } \\
\text { (mL) }\end{array}$ & $\begin{array}{c}\text { Serum } \\
\text { osmolality } \\
\text { (mOsm/L) }\end{array}$ & $\begin{array}{c}\text { Urine } \\
\text { osmolality } \\
\text { (mOsm/L) }\end{array}$ \\
\hline 1 & 141 & 1600 & 282 & 360 \\
2 & 136 & 3380 & 280 & 468 \\
3 & 135 & 5600 & Not available & Not available \\
4 & 136 & 7200 & Not available & Not available \\
5 & 134 & 4650 & 281 & 389 \\
6 & 133 & 2350 & 278 & 366 \\
7 & 120 & 2100 & 274 & 570 \\
8 & 117 & 2000 & 261 & 550 \\
9 & 128 & 4000 & 268 & 541 \\
10 & 132 & 4300 & 268 & 299 \\
\hline
\end{tabular}

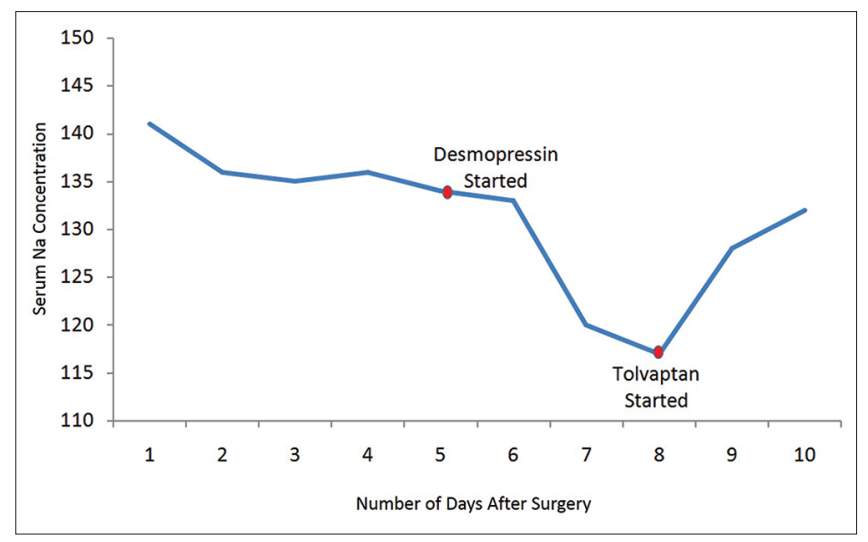

Figure 1: Trend of daily serum sodium and effect of drugs

Tolvaptan is one of the potent, highly selective, and orally effective nonpeptide antagonists of arginine vasopressin. It is a selective oral antagonist of the V2 receptor causing a dose-dependent increase of dilute urine. Tolvaptan has been used for euvolemic and hypervolaemic hyponatraemia. The daily doses of tolvaptan ranges from 15 to $60 \mathrm{mg} .{ }^{[3]}$ Two randomized, placebo-controlled, double-blind phase three clinical trials (SALT-1 and SALT-2) showed the effectiveness of the oral tolvaptan compared with placebo in increasing serum sodium concentrations. ${ }^{[2]}$ Tolvaptan is well-tolerated, the common side effects with prolonged use are nausea, dry mouth, pollakiuria and polydipsia. ${ }^{[3]}$

In the present case, the child had developed hyponatraemia due to desmopressin. The desmopressin is a long-acting vasopressin agonist. There is a wide inter-individual variation in dose requirement and dosing intervals. ${ }^{[4]}$ Dilutional hyponatraemia is a serious adverse effect of desmopressin. This complication mostly develops in the patients within 14 days or less after starting the medication. ${ }^{[5]}$ The oral tablet form has unpredictable absorption. The usual recommended dose is $100 \mu \mathrm{g}$ daily. In the present case, the effect of desmopressin was prolonged resulting in the failure of the treatment of hyponatraemia even after stopping desmopressin and starting hypertonic saline infusion. Though vaptans are recommended for the chronic hyponatraemia due to the pathological conditions, tolvaptan was given in this case to combat the effect of desmopressin resulting in the successful management of hyponatraemia.

Desmopressin should be avoided in the acute and sub-acute stage of hyponatraemia after the neurosurgical intervention. If patients develop the refractory hyponatraemia due to desmopressin use, tolvaptan is effective in restoring the normal serum sodium concentration.

\section{Financial support and sponsorship}

Nil.

\section{Conflicts of interest}

There are no conflicts of interest.

\section{REFERENCES}

1. Lee JJ, Kilonzo K, Nistico A, Yeates K. Management of hyponatremia. CMAJ 2014;186:E281-6.

2. Verbalis JG, Grossman A, Höybye C, Runkle I. Review and analysis of differing regulatory indications and expert panel guidelines for the treatment of hyponatremia. Curr Med Res Opin 2014;30:1201-7.

3. Rangarajan B, Binoy V, Hingmire SS, Noronha V. Tolvaptan. South Asian J Cancer 2014;3:182-4.

4. Ooi HL, Maguire AM, Ambler GR. Desmopressin administration in children with central diabetes insipidus: A retrospective review. J Pediatr Endocrinol Metab 2013;26:1047-52.

5. Lucchini B, Simonetti GD, Ceschi A, Lava SA, Faré PB, Bianchetti MG. Severe signs of hyponatremia secondary to desmopressin treatment for enuresis: A systematic review. J Pediatr Urol 2013;9 (6 Pt B):1049-53.

This is an open access article distributed under the terms of the Creative Commons Attribution-NonCommercial-ShareAlike 3.0 License, which allows others to remix, tweak, and build upon the work non-commercially, as long as the author is credited and the new creations are licensed under the identical terms.

\begin{tabular}{|l|l|}
\hline \multicolumn{2}{|c|}{ Access this article online } \\
\hline Quick Response Code: & Website: \\
\hline & www.jnaccjournal.org \\
\cline { 2 - 2 } & \\
\hline
\end{tabular}

